\title{
FUTURE MODEL OF RESEARCH AND INNOVATION IN CREATIVE INDUSTRIES
}

\author{
AHMAD RASDAN ISMAIL* \\ ABU HASSAN HASBULLAH ${ }^{* *}$ \\ KHAIRUL AZHAR MAT DAUD*** \\ NIK ZULKARNAEN KHIDZIR**** \\ SURIATINI ISMAIL***** \\ MOHD FIRDAUS MAHAMAD ALI******
}

\begin{abstract}
Abstrak
Perkembangan pesat industri kreatif pada abad ke-21 telah membuka pintu peluang terutamanya dalam sektor guna tenaga yang memberikan sumbangan penting kepada pertumbuhan ekonomi sesebuah negara. Perkembangan ini telah menimbulkan fenomena "masa hadapan kreatif" bagi abad ke-21 di mana pada masa yang sama kemajuan mendadak dalam bidang sains dan teknologi berlaku dengan ciptaan pelbagai rangkaian komunikasi dan media baru di mana internet telah menjadi elemen paling penting dalam sistem kehidupan. Secara umumnya, industri kreatif yang dikaitkan dengan hubungan manusia antara penerbitan atau pengeluaran, pengedaran atau pengagihan, pertukaran atau pameran, penggunaan barangan dan menyediakan perundangan/perkhidmatan suapan kepada budaya, seni, estetik, intelek, dan emosi kepada pelanggan di pasaran. Di samping itu juga proses kebudayaan seperti reka bentuk bertujuan membawa keluar kesan yang kuat dalam semua aspek kehidupan yang bergabung secara langsung dengan penggunaan komoditi. Kertas kerja ini bertujuan mengupas model integrasi baru penyelidikan dan inovasi yang dapat mengintegrasikan kepelbagaian disiplin pengetahuan dan sinergi output penyelidikan dan inovasi melalui pengkomersialan.
\end{abstract}

Kata Kunci: Kreatif, Teknologi, Ekonomi, Pengkomersialan

\footnotetext{
* PhD,Profesor Madya dan Ketua Unit Pengurusan Persekitaran, Keselamatan Dan Kesihatan Pekerjaan UMK.

** PhD,Profesor dan Dekan di Fakulti Teknologi Kreatif \& Warisan, Universiti Malaysia Kelantan (UMK).

*** PhD dan Timbalan Dekan di Fakulti Teknologi Kreatif \& Warisan, Universiti Malaysia Kelantan (UMK).

**** PhD dan Timbalan Dekan di Fakulti Teknologi Kreatif dan Warisan, Universiti Malaysia Kelantan (UMK).

***** PhD dan Penyelaras Program Senibina \& Ekistik di Fakulti Teknologi Kreatif \& Warisan, Universiti Malaysia Kelantan (UMK).

****** Pensyarah di Fakulti Teknologi Kreatif \& Warisan, Universiti Malaysia Kelantan (UMK).
} 


\begin{abstract}
The rapid progression of creative industries in the 21st century has opened up doors of opportunities especially in employments thus contributing significantly to the growth of a country's economy. This development has given rise to the phenomenon of "creative futures" of the 21 st Century in which at the same time meteoric advancement in science and technology is taking place with the invention of a variety of communication networks and new media where the internet has been, by far, the most important feature of living systems. Generally, creative industries are to be associated with human creation, publishing or production, circulation or distribution, exchange or exhibition, consumption of goods and to provide attorney/services in order to feed cultural, artistic, aesthetic, intellectual, and emotional to customers in the market. Further in cultural processes such as design aims at bringing out a strong impression in all aspects of life directly affiliated with the consumption of commodities. This paper intentionally to address the new integration model of research and innovation that able to integrate the multiple discipline of knowledge and synergy the output of research and innovation through commercializations.
\end{abstract}

Keywords: Creative, Technology, Economy, Commercialization

\footnotetext{
* PhD,Profesor Madya dan Ketua Unit Pengurusan Persekitaran, Keselamatan Dan Kesihatan Pekerjaan UMK.

** PhD,Profesor dan Dekan di Fakulti Teknologi Kreatif \& Warisan, Universiti Malaysia Kelantan (UMK).

*** PhD dan Timbalan Dekan di Fakulti Teknologi Kreatif \& Warisan, Universiti Malaysia Kelantan (UMK).

**** PhD dan Timbalan Dekan di Fakulti Teknologi Kreatif dan Warisan, Universiti Malaysia Kelantan (UMK).

***** PhD dan Penyelaras Program Senibina \& Ekistik di Fakulti Teknologi Kreatif \& Warisan, Universiti Malaysia Kelantan (UMK).

****** Pensyarah di Fakulti Teknologi Kreatif \& Warisan, Universiti Malaysia Kelantan (UMK) 


\subsection{Introduction}

Creativity is central in the arts and media industry as it provides inputs for all sectors particularly in terms of form and content design in the global economic circles. This development has given rise to the phenomenon of "creative futures" of the 21 st Century in which at the same time meteoric advancement in science and technology is taking place with the invention of a variety of communication networks and new media where the internet has been, by far, the most important feature of living systems.

The fusion of creativity and technology paves a new path in today's and future's growth and prosperity. The amalgamation of creativity and technology is one of the key ingredients to ensure today's and future's economic success especially by developing internationally competitive products and services (Castells, 1996). Creative industries, which have their origins in individual creativity, skills and talents, have exponentially contributed to wealth and job creations by ways of generating and exploiting intellectual property. The following list, which although by no means exhaustive, sufficiently indicates the vast scope of creative industries: advertising, architecture, the arts and antiques market, crafts, design, designer fashion, film and video, interactive leisure software, music, performing arts, publishing, software and computer services, television and radio (Rosso, 2012).

The growth of creative industry is linked to the rise of cultural industries particularly in all aspects of production, distribution and consumption of the economy and the increase in the influence and interests of services sector. This is directly related to the new economic gravitational dynamism marked by influence and power: Attention Economy/ Gift Economy/ Economy Innovation/ Creative Economy. They are in the forms of informational, global and networking. Generally, creative industries are to be associated with human creation, publishing or production, circulation or distribution, exchange or exhibition, consumption of goods and to provide attorney/services in order to feed cultural, artistic, aesthetic, intellectual, and emotional to customers in the market. Further in cultural processes such as design aims at bringing out a strong impression in all aspects of life directly affiliated with the consumption of commodities.

Culture is no longer a mere belief and practice in the social life, but it covers all forms and contents of the system and way of human life: ranging from urban design, officials, houses, architecture, statues, transportation and communication systems, through fashion on how clothing identity gives meaning to wearers and spectators, to promotional strategies on how the government manages ecopocial promotional culture in the age of electronic commerce and the mainpulation of barrage of constrcution and agricultural sectors, entertainment and media in order to meet the needs of economic innovation through creative economic policies (Flew, 2002). At the moment there are lack of study indicated the model of research and innovation that able to aspires and excel the glorious R\&D in Malaysia by the manipulation of traditions, heritage, faith and culture so as to be able to potentially dominate the area of creative economy. 


\subsection{Research and Innovation of Creative Technology}

The research and innovation of Creative Technology are to combine art, science, and technology or to create new products that other people can use. Product design research covers Industrial Design, Services, Software and Physical Product Design. Industrial design is concerned with bringing artistic form and usability, usually associated with craft design and ergonomics in order to mass-produce goods. Fashion industry produces creative extravagance and materialistic needs for the people. Visual communication designers, for instance, may run the gamut from initial business ideas to business successes. Fine arts play significant roles in art galleries, museums, theatre, film and crafts, advertising and marketing, exhibition design, publishing and illustrating. The details of the industries under the Technology Creative indicated in subtopics.

\subsection{Product Design}

Product Design is essentially the efficient and effective generation and development of ideas through a process that leads to new products. In a systematic approach, product designers conceptualize and evaluate ideas, turning them into tangible inventions and products. The role of group members is to combine art, science, and technology to create new products that other people can use. The product design here is not only industrial design but it also covers services, software, and physical product design. Industrial design is concerned with bringing artistic form and usability, usually associated with craft design and ergonomics in order to mass-produce goods. Other aspects of product design include engineering design, particularly when matters of functionality or utility (e.g. problem-solving) are at issue, though such boundaries are not always clear. A product design can be a help of evidence.

\subsection{Textile Fashion}

The art is influenced by cultural and social attitudes and it has evolved over time and place. Fashion designing has come a long way from the designer clothes worn by the royalty of the ancient world to the haute couture products of the present. Fashion designing is one of the most lucrative, appealing, glamorous and exciting career options in today's world. If you have a penchant for creativity, style and originality, a career in fashion designing is the one tailor made for you. On one hand, the fashion industry satisfies both the creative extravagance and materialistic needs for the people. On the other hand, it promises glamour, fame, success and highly paid salaries to talented people.

\subsection{Communication Design}

The communication design runs the gamut from initial business ideas to business successes. Throughout their careers, graphic designers often fend for themselves. As such, designers must create a recognizable brand that allows them to be free in their vision, and also attracts the right kind of business to be financially secure. A graphic designer may perform various tasks: keeping up with the latest trends in the industry, illustrating new concepts, gathering materials for better work performance and coordinating with other agencies or designers on a project.

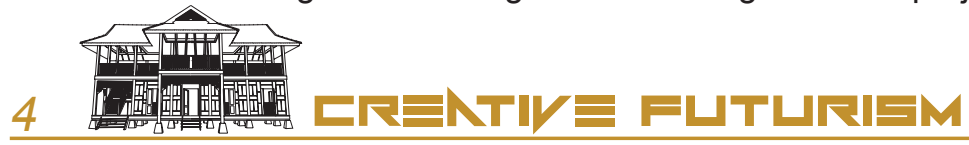




\subsection{Fine Arts}

The contemporary fine art, philosophy, discourse and immersive art practice with inventive intersections of 'old' and 'new' technologies: painting; sculpture; print-making; photography; mixed reality labs; archive and installation; electronic-digital; acoustics; media arts and the new sciences - alongside the questions of embodiment, in corporeality and the queering of sense. This group of creative arts has more to offer and it plays a significant role in art galleries and museums, theatre, film and crafts, advertising and marketing, exhibition design, publishing and illustrating.

\subsection{Research and Innovation in Cyberology}

Cyberology responsible in creating new digital products for customers' consumptions. In a broader concept, Cyberology is essentially the efficient and effective generation and development of ideas through a process that leads to new products. In a systematic approach, cyberologist whose expertise in virtual reality technology (VRT), Animation and Ludology, media and robotics design, conceptualize and evaluate ideas, turning them into tangible inventions and digital products. The role of group members is to combine art, science and technology to create new products that other people can use.

The example of cyberology products is virtual model for construction, tourism, graphic, simulation, animation for games, movie, entertainment, performance, information deployed, Media for digital journalism, e-book, e-commerce, and robotic for consumer product. Other aspects of Cyberology include cyberspace, cybergogy, cybernetics and anything related to digital and online system in monitoring physical robotic mechanisms. Further the fields of cyberology are listed below:

\subsection{Cyber Management}

Cyber Management, the management structure of the future, is designed to respond quickly and effectively to the changing needs of the information technology environment goes a step further in encouraging team evolution. Similar to elements of a living organism, members from various sections come together to respond to challenges arise, thus the pool of members coming together unites individual strengths and talents of each team member towards achieving a specific goal. This field focuses on any study related to cyber space from technical aspects to humanity and society. (e.g cyber security, cyber law, cyber society, etc).

\subsection{Virtual Reality Technology}

Virtual Reality (VR), sometimes referred to as immersive multimedia, is a computer-simulated environment that can simulate physical presence in places in the real world or imagined worlds. Virtual reality could recreate sensory experiences, including virtual taste, sight, smell, sound, touch, etc. Virtual reality is often used to describe a wide variety of applications commonly associated with immersive, highly visual, 3D environments. The development of CAD software, graphics hardware acceleration, head-mounted displays, datagloves, and miniaturization have helped popularize the notion. In the book 
The Metaphysics of Virtual Reality by Michael R. Heim, seven different concepts of virtual reality are identified: simulation, interaction, artificiality, immersion, telepresence, full-body immersion, and network communication. People often identify VR with head mounted displays and data suits (Heim, 1994).

Virtual reality technology faces a number of challenges, most of which involve technical matters and Simulation sickness due to virtual reality (Oculus Rift is working to solve simulator sickness). Users might become disoriented in a purely 'virtual' environment, causing balance issues; computer latency might affect the simulation, providing a less-than-satisfactory end-user experience; the complicated nature of head-mounted displays and input systems such as specialized gloves and boots may require specialized training to operate, and navigating the 'real' environment (if the user is not confined to a limited area) might prove dangerous without 'external' sensory information.

\subsection{Animation and Ludology}

Animation is the process of creating a continuous motion and shape change illusion by means of the rapid display of a sequence of static images that minimally differ from each other. Animations can be recorded on either analogue media, such as a flip book, motion picture film, video tape, or on digital media, including formats such as animated GIF, Flash animation or digital video. To display it, a digital camera, computer, or projector are used.

Computer animation encompasses a variety of techniques, the unifying factor being that the animation is created digitally on a computer. $2 \mathrm{D}$ animation techniques tend to focus on image manipulation while $3 \mathrm{D}$ techniques usually build virtual worlds in which characters and objects move and interact. 3D animation can create images that seem real to the viewer.

Game studies or gaming theory or Ludology is a discipline that deals with the critical study of games. More specifically, it focuses on game design, players, and their role in society and culture. Game studies is an inter-disciplinary field with researchers and academics from a multitude of other areas such as computer science, psychology, sociology, anthropology, philosophy, arts and literature, media studies, communication, theology, and many more. Ludology involves textual analysis and audience theory. Game studies tends to employ more diverse methodologies than these other branches, drawing from both social science and humanities approaches (Frasca, 2003).

\subsection{Media Digital}

Digital media are any media encoded in a machine-readable format. Digital media can be created, viewed, distributed, modified and preserved on computers. Computer programs and software; digital video; web pages and websites, including social media; data and databases; digital audio, such as $\mathrm{mp} 3 \mathrm{~s}$; and e-books are examples of digital media. Digital media are frequently contrasted with print media, such as printed books, newspapers and magazines and other traditional or analog media, such as film or audio tape (Robin, 2014).

Digital Media's rapid popularity, usually aided by Internet and personal computing brought a new frontier 
to publishing, journalism, entertainment, education, commerce and politics. It is also related to issues of copyright and intellectual property laws, as well as fostering an open content movement in which content creators voluntarily relinquish the rights to their works. The ubiquity of digital media and its effects on society indicate that a new era of industrial history, known as the Information Age has begun. Digital media may lead to a paperless society.

\subsection{Robotics}

Robotics is the branch of technology that deals with the design, construction, operation, and application of robots, as well as computer systems for their control, automated machines that can take the place of humans in dangerous environments or manufacturing processes, or resemble humans in appearance, behaviour, and/or cognition. Many of today's robots are inspired by nature contributing to the field of bio-inspired robotics.

The concept of creating machines that can operate autonomously dates back to classical times, but research into the functionality and potential uses of robots did not grow substantially until the 20th century. Throughout history, robotics has been often seen to mimic human behavior, and often managed tasks in a similar fashion. Today, robotics is a rapidly growing field, as technological advances, research, design, and building new robots serve various practical purposes, whether domestically, commercially, or militarily. Many robots do jobs that are hazardous to people such as defusing bombs, mines and exploring shipwrecks (Lisa, 2007).

\subsection{Research and Innovation in Ekistics}

Ekistics has been defined by scholars (including C. A. Doxiadis) since 1956 as a global science of human settlement (small or large, ancient, modern or future, isolated, in group or regions, examined whole or in constituent parts from all aspects including geographic, economic, social cultural, administrative, legal aesthetic and technological). The notion implies that understanding the interaction between (and within) human groups-shelter, infrastructure and function (job) - in conjunction with their environment (including built environment) directly affects their well-being (individual and collective). In conjunction with this, the sub-cluster's main function is to create research opportunities that can produce innovative and sustainable design and management through the adoption of mega trends and mega cities concept with heritage and entrepreneurial characteristics as a strategic niche area.

\subsection{Built Environment}

The built environment group focuses on the built form in creative building industries. It covers the three main areas; architecture, landscape architecture, interior architecture and urban built futures (McLennan, 2004). The cluster niche area shall be on sustainable design; vernacular \& heritage architecture, sustainable building technology and sustainable design are the main focus of this group. This is in line with the notion of ekistics which implies that understanding the interaction between (and 
within) human groups shelter, infrastructure and function (job) -- in conjunction with their environment (including built environment) directly affects their well-being (individual and collective).

\subsection{Built Environment}

The built environment management (BEM) group focuses on the management aspects of creative building industries. The emphasis is on multidisciplinary research towards sustainable urban futures. It covers areas on quantity surveying, asset management, project planning, facilities management and urban futures. As such mega cities and mega trends are the points of reference to all researches undertaken. This is consistent with the notion of ekistics which implies that understanding the interaction between (and within) human groups-shelter, infrastructure and function (job) -- in conjunction with their environment (including built environment) directly affects their well-being (individual and collective).

\subsection{The Function of Integration of Creative Industries}

The creative industries on this hand based on the integration between three clouds represented by concurrent three branches of tree illustrated in Figure 1. This combination research agenda between creative technology, cyberology and ekistics expected to blossom with other tangible output related output to generate the revenues (Abu Hassan, 2013). The economics driven to generate the commercialization and revenue will serve as the roots of creative industry tree.

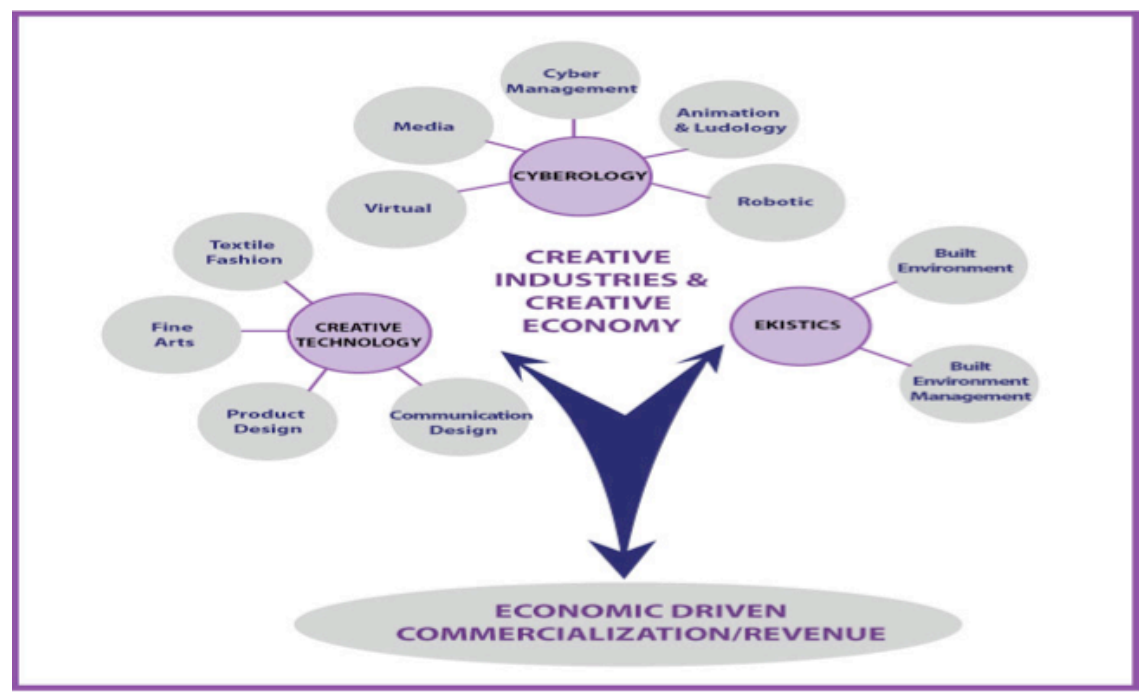

Figure 1: Branches of main discipline under creative industries

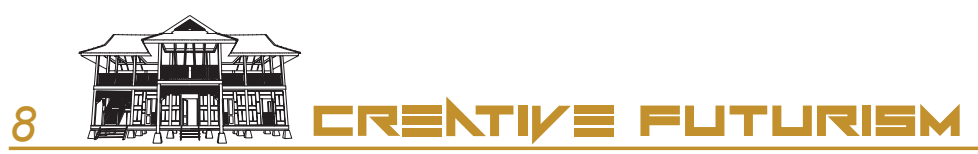




\subsection{STRATEGIC RESEARCH ACTION PLAN}

6.1 The collaborative input output model

In general, CIN views this endeavour as collaborative efforts between the expertise presence in $\mathrm{CIN}$ and other research clusters which make up the university resources or inputs. The inputs are blended together to form a strong force that can contribute to the society in constructing a harmonious community-socially, economically and environmentally sustainable.

\subsection{Strategic Research Niche (SRN)}

Under the strategic planning of research, the Niche areas in which CIN can explore are illustrated in Figure 2. The combination of research niche clouds will intercept between each under and the transmission of the whole output to the manufacturing as well as servicing sectors will be channel to the commercialization entity under the faculty which is so called the MONSUN industries. This entity responsible in strengthening the commercialization and entrepreuneur of the $\mathrm{CIN}$ output.

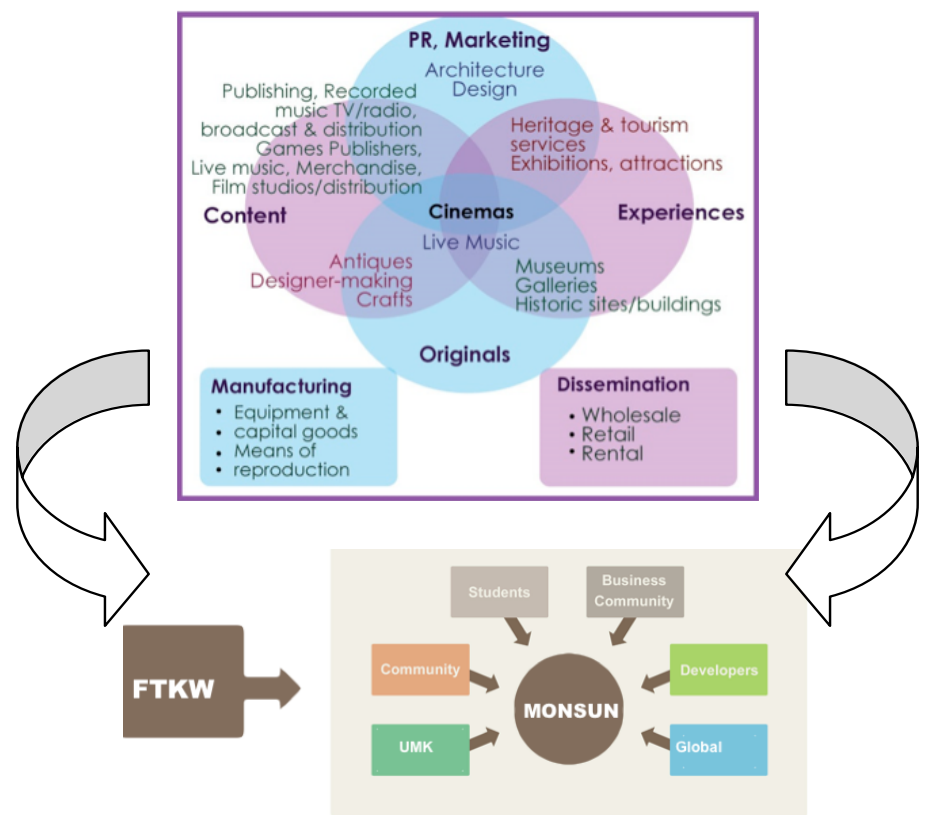

Figure 2: Strategic Research Niche 


\subsection{The Function of Integration of Creative Industries}

The creative industries on this hand based on the integration between three clouds represented by concurrent three branches of tree illustrated in Figure 1. This combination research agenda between creative technology, cyberology and ekistics expected to blossom with other tangible output related output to generate the revenues (Abu Hassan, 2013). The economics driven to generate the commercialization and revenue will serve as the roots of creative industry tree.

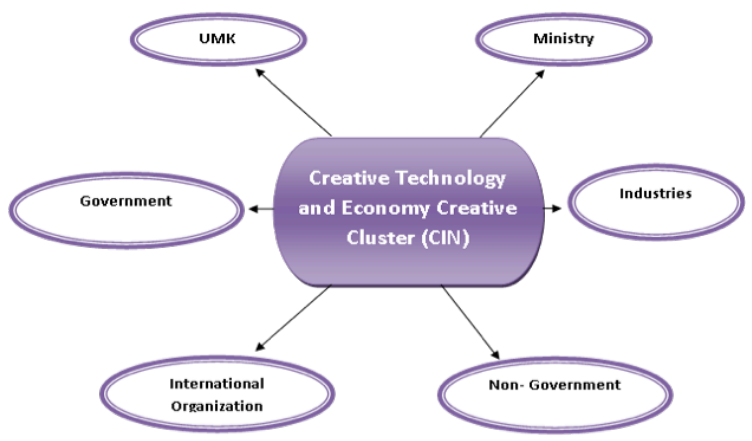

Figure 3: Possible Sources of Funding

\subsection{Intended Key Performance Index}

The expectation of output from CIN generated were not limited to the publications in books, journal articles, proceeding articles, chapters in books, monographs and the other Comics, TV programs, short drama or films and Malaysia Oracle Network on Creative Sustainable Technology and Futures Design (MONSUN). The overall value added chain in creative industries illustrated in Figure 4.

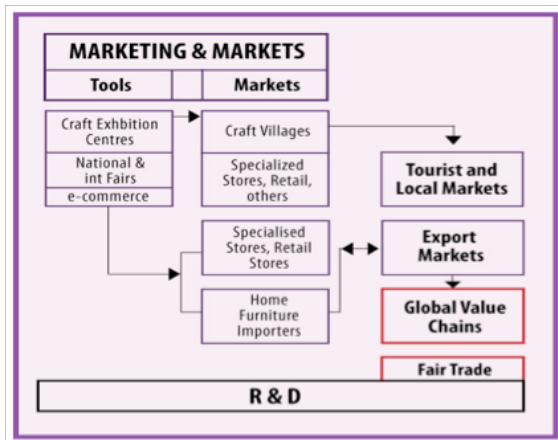

Figure 4: Value added chain in Creative Industries 


\subsection{Milestone Outcome of Research and Innovation in Creative Industries}

The trajectory of research elements and entity will be projected according to the level of output and transformation process. The movement of technologies expected to be extensive transform to the cyber management whereas the creative process will be more value added with the intelligent added and the output expected will be transparent rather than physical. Planned outcomes consist of milestone outcome of CIN. The milestone of the expected outcome of future creative industries illustrated in Figure 5.

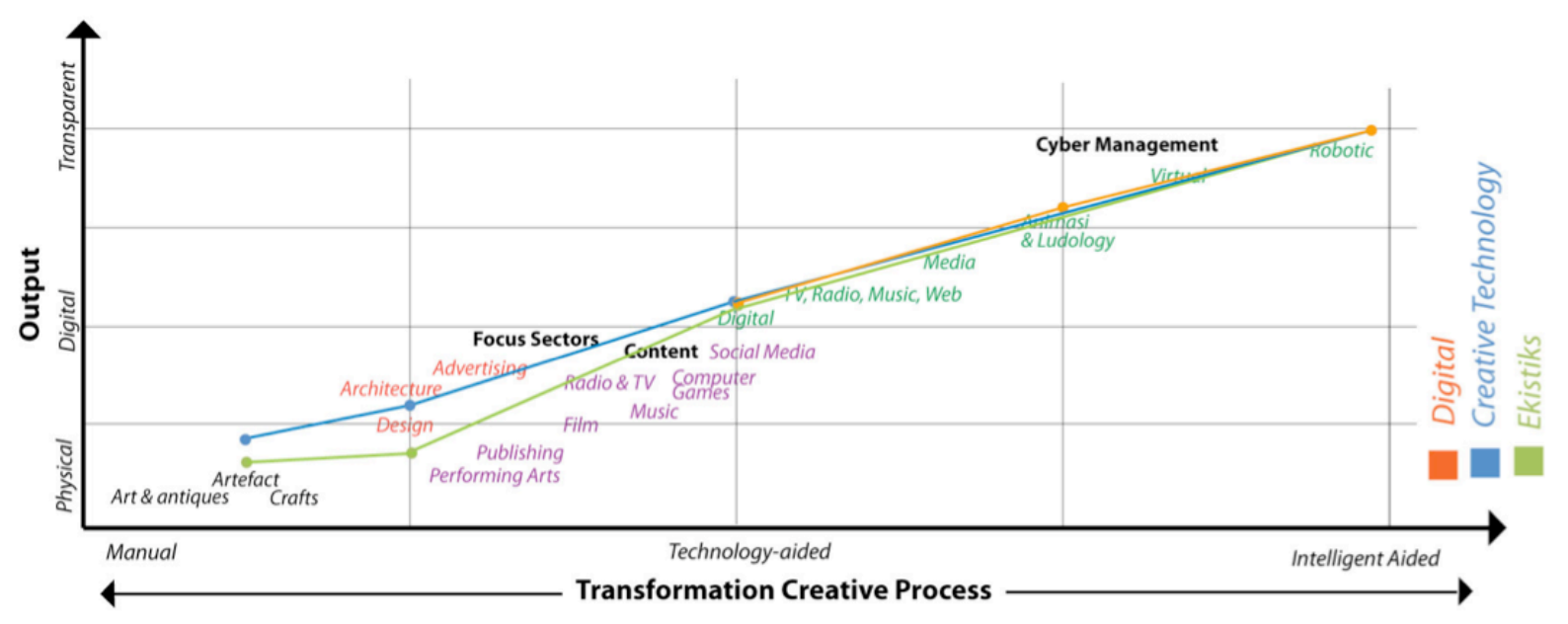

Figure 5: Milestone of Outcome 


\subsection{The target market of Creative Industries}

The possible target market of creative industries is shown in Figure 6 . The based or final output will be economic driven and revenue generated.

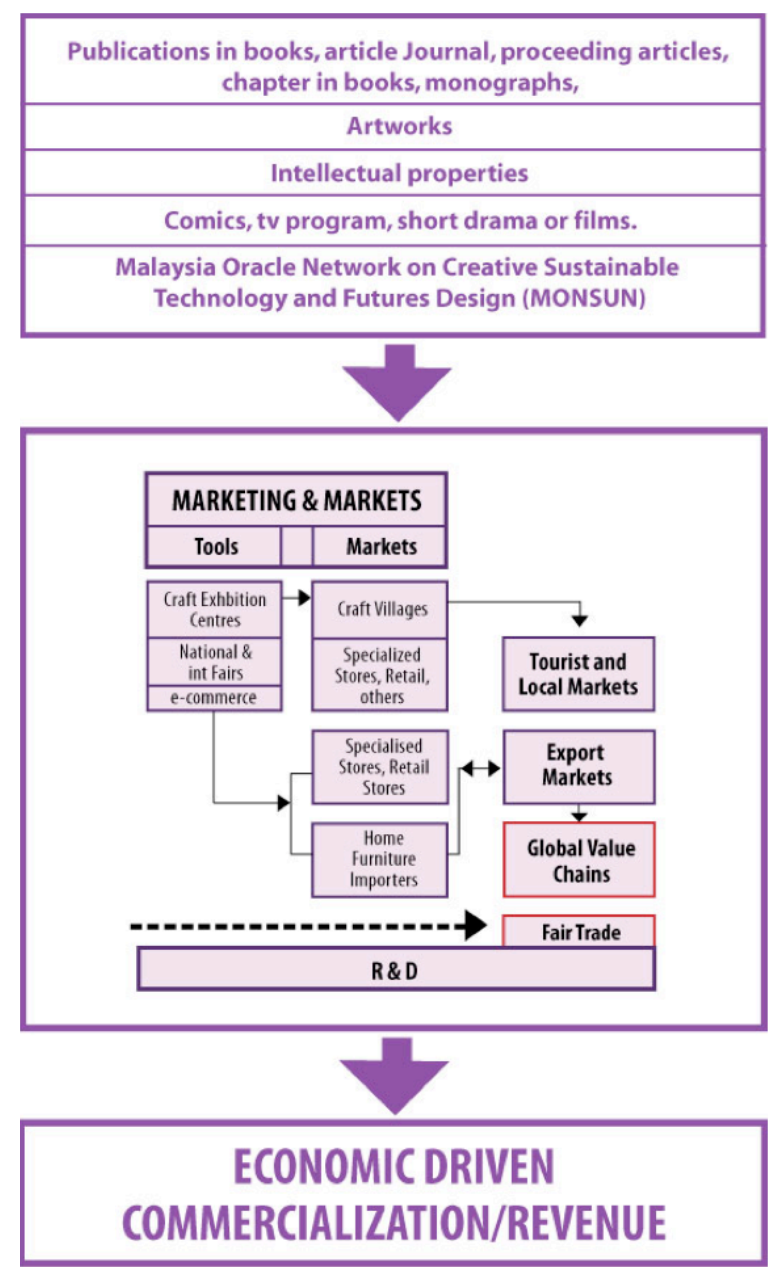

Figure 6: Target Market 


\subsection{Implementation strategy}

The implementation strategy for creative industries is shown in the process Figure 7 . The combination of academics output will be translated to manufacturing and service provided that may lead to the commercialization and revenue generated to the faculty and university.

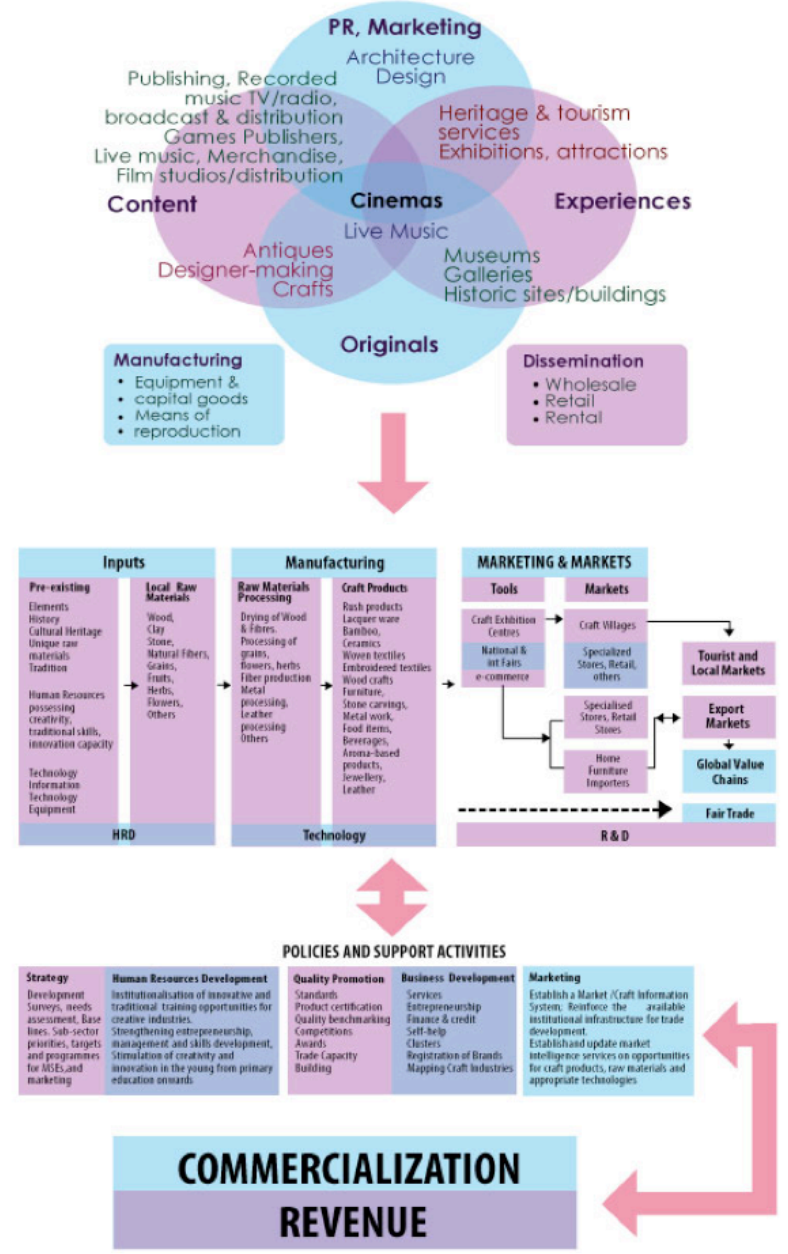

Figure 7: Implementation Strategy for Creative Industry 


\subsection{Conclusion}

The success of this research and innovation activities depends highly on the commitment of the management and members. The proactively plan for all the activities need to be executed by each of the clusters in order to spearhead the research and innovation culture in creative industries. Collaboration from both within UMK and outside of UMK is essential in ensuring the smooth sailing of this visionary endeavour. This plan is drawn to ensure the relevancy of creative industries as well as to realise the dream of turning east coast into a creative industrial hub.

\section{References}

Abu Hassan Hasbullah (2013). "Industri Creative Futures Malaysia: Mengadiluhung Peluang Menjadi Laboritorium Dunia." Jurnal Antarabangsa Creative Futures dan Warisan (TENIAT), Jilid 1, Bil. 1 pg. 1.

Castells, M. (1996). The Rise of the Network Society, Vol. 1 of The Information Age: Economy, Society and Culture. Massachusetts: Blackwell.

Flew, T. (2002). The Second International Conference on Cultural Policy Research: Beyond ad hocery: Defining Creative Industries. 23-26 January. Te Papa, Wellington, New Zealand

Frasca, G. (2003). Simulation versus Narrative: Introduction to Ludology. In Wolf, M. J. P., \& Perron, B. (Eds.), The Video Game Theory Reader (pp.221-235). New York: Routledge.

Heim, M. R., (1994). The Metaphysics of Virtual Reality. Oxford University Press. ISBN: 9780195092585

Hines A., Fontenot D., Howell C. (1996). Cybermanagement in University Setting. "Broadening Our Horizons: Information, Services, Technology - Proceedings of the 1996 CAUSE Annual Conference".

Lisa, N., (2007). The robot : the life story of a technology. Westport, CT: Greenwood Publishing Group.

McLennan, J. F. (2004). The Philosophy of Sustainable Design.

Robin, B. (2014) About Digital Storytelling: What is Digital Storytelling? Retrieved 6 August 2014 from: http://digitalstorytelling.coe.uh.edu/page.cfm?id=27\&cid=27

Rosso, L., 2012, Materials Research and Innovation in the Creative Industries, report on the round table discussion, Brussels, 5th October 2012, European Union.

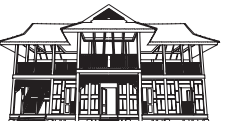

